\title{
U.S. Geological Survey Virginia and West Virginia Water Science Center
}

The U.S. Geological Survey (USGS) serves the Nation by providing reliable scientific information to describe and understand the Earth; minimize loss of life and property from natural disasters; manage water, biological, energy, and mineral resources; and enhance and protect our quality of life. In support of this mission, the USGS Virginia and West Virginia Water Science Center works in cooperation with many entities to provide reliable, impartial scientific information to resource managers, planners, and the public.

\section{A Wide Range of Scientific Expertise}

\section{Hydrologic Monitoring and Analysis}

- Real-time streamgage and tide network operation

- Real-time precipitation network operation

- Streamflow statistics

- Hydrologic modeling

- Flood and drought monitoring, mapping, and analysis

\section{Water-Quality Monitoring and Analysis}

- Monitoring of diverse surface-water and groundwater environments

- State-of-the-art measurement of a broad range of contaminants

- Continuous water-quality monitoring

- Load and trend analysis

- Advanced statistical analysis and method development

\section{Hydrogeologic Monitoring and Analysis}

- Groundwater-level monitoring

- Monitoring of aquifer compaction and land subsidence

- Groundwater modeling

- Assessment of water availability

- Geophysical assessment of aquifer properties and characteristics

\section{Ecological Monitoring and Analysis}

- Fish and aquatic invertebrate monitoring

- Ecotoxicological monitoring

- Ecological streamflow assessment

\section{Geospatial Analysis}

- Geospatial modeling

- Web-based map application development
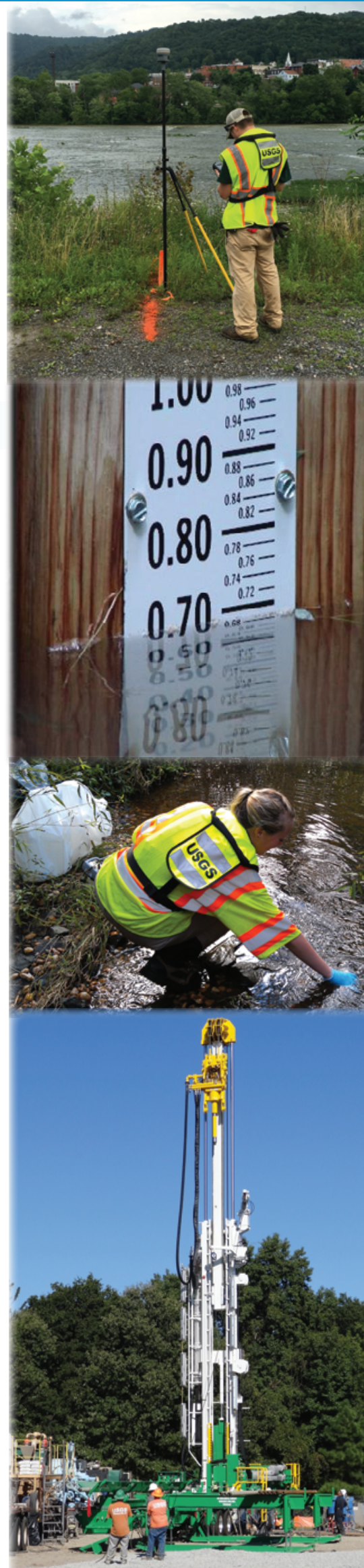
- The Center employs a diverse staff of scientists, technicians, and administrative support professionals in multiple locations throughout Virginia and West Virginia.

- The Center operates and maintains extensive monitoring networks and conducts hydrologic investigations to quantify each component of the hydrologic cycle (fig. 1). These monitoring networks and investigative expertise enable the Center to address nearly any type of water-resources question or hydrologic data-collection need.

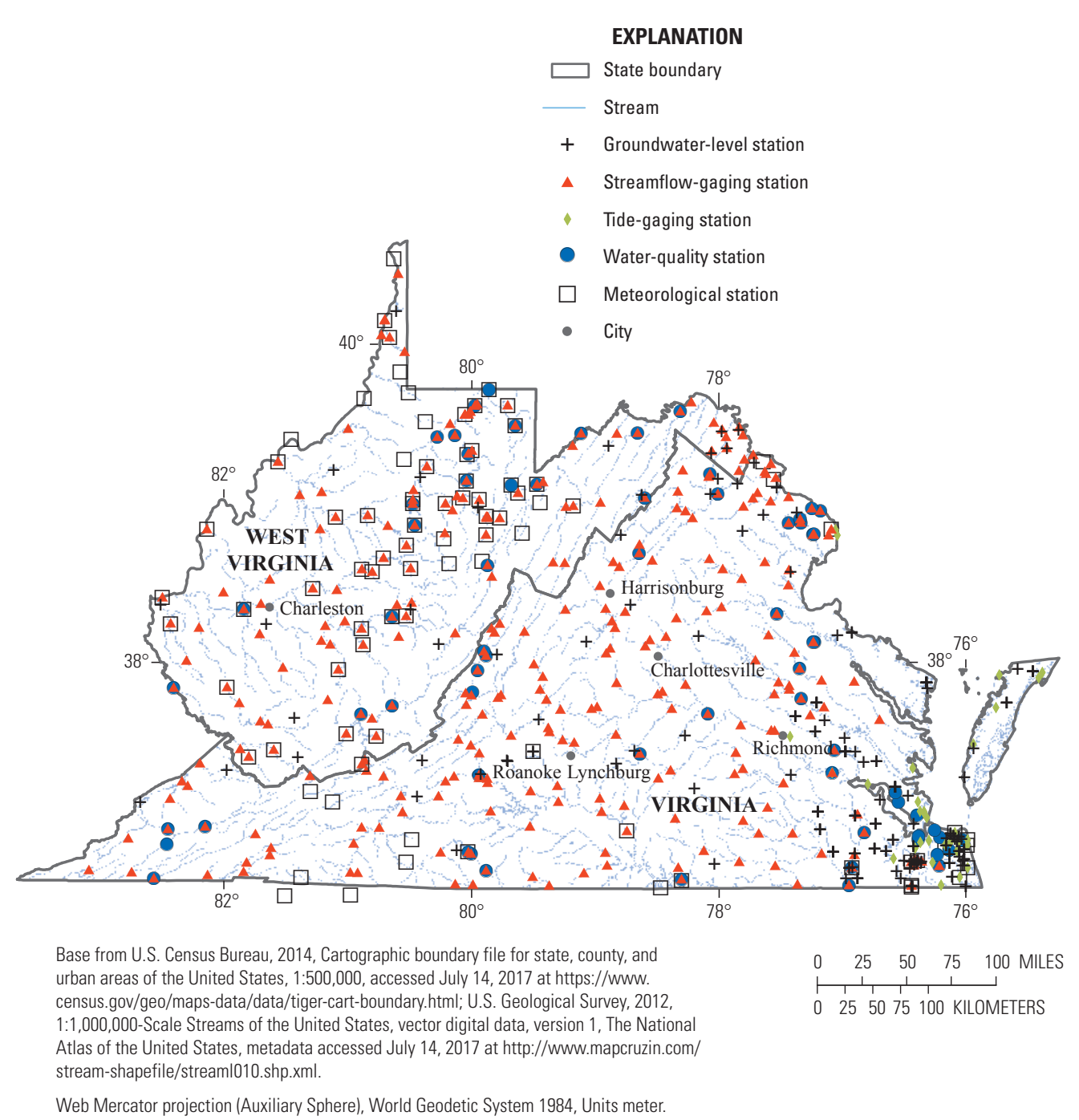

Figure 1. Map of hydrologic monitoring networks operated by the Virginia and West Virginia Water Science Center (Some stations are operated jointly with the Virginia Department of Environmental Quality).

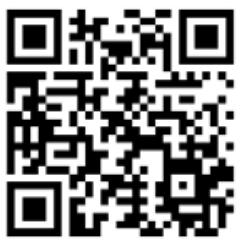

For more information about the Virginia and West Virginia Water Science Center, visit

www.usgs.gov/centers/va-wv-water

\section{Partnering Opportunities}

Most of the monitoring and investigations performed by the Center are conducted in cooperation with Federal, regional, State, and Local agencies, academic institutions, or private/ industrial partners.

For information about opportunities for partnering with the USGS Virginia and West Virginia Water Science Center, contact dc_va@usgs.gov. 